\title{
Heavy metal contamination of selected spices obtained from Nigeria
}

\author{
*11GAYA, UI; IKECHUKWU, SA \\ Department of Pure and Industrial Chemistry, Bayero University Kano, \\ 700241 Kano State, Nigeria \\ *Correspondence author email: uigaya.chm@buk.edu.ng
}

\begin{abstract}
In this study, the levels of trace metals $(\mathrm{Cd}, \mathrm{Cr}, \mathrm{Cu}, \mathrm{Co}, \mathrm{Fe}, \mathrm{Mn}, \mathrm{Ni}, \mathrm{Mo}, \mathrm{Pb}$, $\mathrm{Zn}$ ) in twenty two spices representing four spice groups (seeds, bulbs, leaves, fruit pods and rhizome) from a major market in Northern Nigeria were determined using atomic absorption spectroscopy, and assessed based on regulatory standards. Garlic exhibited the highest zinc concentration $(21.733 \pm 0.044 \mathrm{mg} / \mathrm{kg}$ ), which falls lower than the upper toxic level for most plants. Lead concentrations peaked in African nutmeg $(4.717 \pm 0.017 \mathrm{mg} / \mathrm{kg})$ but are lower than the normative for the final dosage form of medicinal plants. The daily intake-based hazard of the spices was assessed using the minimum risk levels set by WHO, and the FAO/WHO maximum tolerable intake limits. All the spices contain excessive cobalt and copper with maximum levels $(\mathrm{mg} / \mathrm{kg})$ in ginger cobalt $(11.117 \pm 0.069)$ and African nutmeg $(15.300 \pm 0.041)$, respectively. The estimated daily intake values $(\mu \mathrm{g} / \mathrm{kg}$ day) of onion $(1.10)$, ginger (12.00), utazi (1.30), alligator paper (1.20), garlic (0.89), Ashanti leaves (0.88), castor seeds (1.20), and shallot (0.86)were higher than the provisional maximum tolerable intake set by FAO/WHO, constituting a potential risk to human health. These results show that spices can accumulate exceeding levels of toxic metals whose potential risk to human health should be given priority. (C) JASEM

http://dx.doi.org/10.4314/jasem.v20i3.23
\end{abstract}

KEYWORDS: heavy metal; contamination; Nigeria; spices; health; daily intake

Over the millennia, spices have been used in changing world's cuisine and medicine (Dukes, 2003). Regrettably, significant quantities of heavy metals have been detected in natural food spices such as pepper and mustard (Krejpcio, 2007; Khan et al., 2014)].Although low levels of some heavy metals such as chromium, iron, manganese, cobalt, zinc and copper are considered essential, even low levels of other metals such as cadmium and lead can have toxic effects in human biochemical reactions (Järup , 2003; Cao et al., 2010). The accumulation of these important hazardous metals can breed middle-term or long-term health effects manifesting inter alia as depression, chronic asthma, liver damage, insomnia, kidney damage and neurological disorders (Mandal and Suzuki, 2002; Barakat, 2011).

Generally speaking, $\mathrm{Cd}, \mathrm{Pb}, \mathrm{Cr}, \mathrm{Cu}, \mathrm{Zn}$, As and $\mathrm{Ni}$ are the most hazardous heavy metals in the environment (Brimer, 2011). Despite being the most ecotoxic metal, lead resides naturally in plants. Recently, $\mathrm{Pb}$ and $\mathrm{Cd}$ were listed by the Agency for Toxic Substances and Disease Registry (ATSDR, 2015) as second and seventh priority toxic substances. Consequent upon this, it is imperative to monitor the hazardous effect of the heavy metal in common condiments. In a study, Egyptian spices were found to contain alarming levels of $\mathrm{Pb}, \mathrm{Cd}, \mathrm{Cr}$, $\mathrm{Sn}, \mathrm{Mn}, \mathrm{Zn}, \mathrm{Co}, \mathrm{Cu}, \mathrm{Fe}$ and Ni (Abou-Arab \& Abou Donia, 2000).
Admittedly, the extent of contamination of the spices with heavy metal varies from one plant to another. Reasons for this variation have been revealed by the work of Chizzola et al. (2003), which determined the levels of $\mathrm{Cd}, \mathrm{Fe}, \mathrm{Cu}, \mathrm{Zn}$ and $\mathrm{Pb}$ in spices, aromatic and medicinal plants from different regions of Austria and confirmed that the tendency to accumulate $\mathrm{Cd}$ is species dependent while $\mathrm{Pb}$ uptake occurs rather by chance.

Nigerians are prone to spicy foods which lends them to the associated consequences. Previously, the levels of $\mathrm{Cd}, \mathrm{Pb}, \mathrm{Cu}, \mathrm{Cr}, \mathrm{Ni}, \mathrm{Fe}$ and $\mathrm{Zn}$ have been determined in Nigerian sesame (Obiajunwa et al., 2005) and some Nigerian spices from Warri (Iwegbue et al., 2011).In this study, we investigate various common spices for possible metal $(\mathrm{Pb}, \mathrm{Cu}, \mathrm{Cd}, \mathrm{Zn}$, $\mathrm{Cr}, \mathrm{Co}, \mathrm{Ni}, \mathrm{Mo}, \mathrm{Fe}$ and $\mathrm{Mn}$ )contamination.

\section{MATERIALS AND METHODS}

Sample Collection and Preparation: Twenty two different spices were obtained from Yankura, Abubakar Rimi market, Kano metropolis (lat. 11 ${ }^{\circ}$ $30 \mathrm{~N}$, long. $\left.8^{\circ} 38 \mathrm{E}\right)$. The samples were categorized as bulbs, fruit pods, leaves, rhizome or seeds. The scientific name of the plants and the plant part used in the study are listed in

Table 1 
Table 1: List of the spices investigated with their groups, and botanical names of the source plants.

\begin{tabular}{lll}
\hline Spice group & Plant & Botanical name \\
\hline Bulbs & Onions & Allium cepa \\
& Shallot & Allium aggregatum \\
& Garlic & Allium sativum \\
Rhizome & Ginger & Zingiber officinale \\
Seeds & Alligator Pepper & Aframomum melegueta \\
& Cloves & Syzygium aromaticum \\
& African nutmeg & Monodora myristica \\
& Ashanti Pepper & Piper guineense \\
& Efu & Monodoro Sp \\
& African locust bean & Parkia biglobosa \\
& Melon & Citrullus lanatus \\
& Castor seed & Ricinus communis \\
& Nutmeg & Myristica fragrans \\
& Uziza & Piper guineense \\
& Curry & Murraya koenigii \\
& Scent leaves & Ocimum gratissimum \\
& Utazi & Gongronema latifolium \\
& Bay leaves & Lauras noiblis \\
& Red chili pepper & Capsicum annum \\
& Yellow pepper & Capsicum annum \\
& Red bell pepper & Capsicum annum \\
& African pepper & Xylopia aethiopica \\
\hline & &
\end{tabular}

In order to ensure that metals determined are exclusively those uptaken by the plants, each sample was thoroughly washed with tap water and then with deionized water. The samples were then dried in air, followed by oven drying at $80{ }^{\circ} \mathrm{C}$ until constant weight. The dry samples were ground to fine particle and stored in airtight nylons.

Sample Preparation and Digestion: Metal extraction was accomplished by the wet digestion. Exactly $1 \mathrm{~g}$ of dry spice powder was weighed into 250 $\mathrm{cm}^{3}$ beakers, mixed with $20 \mathrm{~cm}^{3}$ of $2: 1 \mathrm{HNO}_{3} / \mathrm{HClO}_{4}$ and heated in a fume cupboard for 5-10 min using hot plate. Completion of digestion was marked by the evolution of white fumes. The digests were allowed to cool, diluted with deionized water (to avoid chemical attack of filter paper), then filtered into $50 \mathrm{~cm}^{3}$ standard volumetric flask and made up to the mark with the deionized water. Calibration standards as well as blank were prepared at the same time as the samples. All standards were prepared from nitrates (in concentrations of $0,0.1,0.2,0.4,0.6,0.8$, and 1 $\mathrm{mg} / \mathrm{dm}^{3}$ ) except for molybdenum and manganese which were prepared from $\left(\mathrm{NH}_{4}\right)_{2} \mathrm{MoO}_{24} \cdot 4 \mathrm{H}_{2} \mathrm{O}$ and $\mathrm{MnCl}_{2}$, respectively.

Heavy Metal Determination: The filtrate resulting from wet digestion was subsequently analyzed for $\mathrm{Pb}$, $\mathrm{Cu}, \mathrm{Fe}, \mathrm{Cd}, \mathrm{Zn}, \mathrm{Cr}, \mathrm{Co}, \mathrm{Ni}, \mathrm{Mo}$, and $\mathrm{Mn}$ using Hitachi Z-5000 flame atomic absorption spectrophotometer(AAS). The AAS was fueled by acetylene. Standards were analyzed accordingly but devoid of the spice. Chromium was determined in the +3 oxidation state and the standard used was $\mathrm{Cr}$
$\left(\mathrm{NO}_{3}\right)_{3} \cdot 9 \mathrm{H}_{2} \mathrm{O}$. The actual concentrations were extrapolated from calibration curves. Analytical concentrations in $\mathrm{mg} / \mathrm{dm}^{3}$ were converted to $\mathrm{mg} / \mathrm{kg}$. Each analysis was repeated twice and standard deviations from the mean values were calculated.

Human Health Risk Assessment: The health risk associated with the consumption of the spices under study was estimated based on daily intake as estimated daily intake (EDI). This parameter was calculated on the uniform basis of $10 \mathrm{~g}$ raw spice per $60 \mathrm{~kg}$ body weight.

$$
E D I=\frac{(C \times A C)}{b w}
$$

$\mathrm{C}(\mathrm{mg} / \mathrm{kg})$ is the concentration of heavy metals in the raw spice, AC is the average dry weight of the spice consumed by local inhabitants based on $\mathrm{g} \mathrm{day}^{-1}$ person $^{-1}$ and bw is the average adult body weight $(60 \mathrm{~g})$.

Quality Control: The method of AAS analysis was validated by recovery method. Samples of onions, melon, garlic, scent leaves and African pepper were spiked with $\mathrm{Fe}, \mathrm{Cu}, \mathrm{Mn}, \mathrm{Zn}$, and Mo doses, respectively. In a typical recovery test, exactly 1 $\mathrm{mg} / \mathrm{dm}^{3}$ of the metal was added to $1 \mathrm{~g}$ of each of the samples in a $250 \mathrm{~cm}^{3}$ beaker and digested with $20 \mathrm{~cm}^{3}$ 2:1 $\mathrm{HNO}_{3} / \mathrm{HClO}_{4}$. The digest was treated as described above. Percentage recovery was calculated using the relation:

$$
\text { Recovery }(\%)=\frac{\text { Amount determined }}{\text { Amount added }} \times 100
$$


The results of the recovery of spikes of $\mathrm{Fe}, \mathrm{Cu}, \mathrm{Mn}$, $\mathrm{Zn}$, and Mo from onions, melon, garlic, scent leaves and African pepper, which were 90\%, 89\%, 90\%, $95 \%$ and $97 \%$ respectively, which validates the method and assures its quality (Table 2). In other words all the metal recoveries are within $11 \%$ of the true concentrations, thus attesting the suitability of the AAS method.

Table 2: Metal recovery efficiencies as $5 \mathrm{mg} / \mathrm{dm}^{3}$ heavy metal is augmented.

\begin{tabular}{llcccc}
\hline Metals & Spice sample & $\begin{array}{c}\text { Initial conc. } \\
(\mathrm{mg} / \mathrm{kg})\end{array}$ & $\begin{array}{c}\text { Final conc. } \\
(\mathrm{mg} / \mathrm{kg})\end{array}$ & $\begin{array}{c}\text { Amount } \\
\text { recovered }\end{array}$ & $\begin{array}{c}\text { Recovery } \\
(\%)\end{array}$ \\
\hline $\mathrm{Fe}$ & Onion & 275.90 & 280.65 & 0.90 & 90 \\
$\mathrm{Cu}$ & Melon seed & 2.00 & 6.01 & 0.89 & 89 \\
$\mathrm{Mn}$ & Garlic & 2.28 & 6.78 & 0.90 & 90 \\
$\mathrm{Zn}$ & Scent leaves & 8.88 & 13.65 & 0.95 & 95 \\
$\mathrm{Mo}$ & African pepper & 7.67 & 12.55 & 0.97 & 97 \\
\hline
\end{tabular}

\section{RESULTS AND DISCUSSION}

Assessment of Heavy Metals: The results of heavy metal analysis are presented according to the spice group (seeds, bulbs, leaves, fruit pods and rhizome; Tables 3-7).

Table 3: Descriptive statistics of analytical concentrations $(\mathrm{mg} / \mathrm{kg})$ of heavy metals in seeds

\begin{tabular}{|c|c|c|c|c|c|c|c|c|c|c|c|}
\hline Spices & Statistics & $\mathrm{Cd}$ & $\mathrm{Cr}$ & $\mathrm{Cu}$ & $\mathrm{Co}$ & $\mathrm{Fe}$ & $\mathrm{Mn}$ & $\mathrm{Ni}$ & Mo & $\mathrm{Pb}$ & $\mathrm{Zn}$ \\
\hline \multirow[t]{2}{*}{ Castor } & Mean & 7.800 & 3.150 & 9.450 & 10.550 & 16.667 & 3.750 & 2.733 & 3.233 & 2.700 & 13.050 \\
\hline & SD & 0.054 & 0.010 & 0.027 & 0.019 & 0.084 & 0.025 & 0.014 & 0.033 & 0.011 & 0.022 \\
\hline \multirow[t]{2}{*}{ Baobab } & Mean & 3.200 & 4.067 & 8.100 & 7.217 & 9.733 & 5.000 & 4.100 & 3.783 & 3.433 & 13.050 \\
\hline & SD & 0.021 & 0.011 & 0.027 & 0.020 & 0.048 & 0.043 & 0.014 & 0.018 & 0.023 & 0.022 \\
\hline \multirow[t]{2}{*}{ Efu } & Mean & 3.550 & 4.383 & 9.450 & 9.433 & 13.883 & 5.833 & 3.883 & 4.300 & 3.250 & 14.867 \\
\hline & SD & 0.012 & 0.011 & 0.027 & 0.051 & 0.048 & 0.014 & 0.021 & 0.049 & 0.022 & 0.045 \\
\hline \multirow{2}{*}{$\begin{array}{l}\text { Ashanti } \\
\text { pepper }\end{array}$} & Mean & 4.250 & 3.150 & 7.200 & 9.433 & 18.067 & 6.667 & 4.117 & 6.983 & 2.517 & 14.500 \\
\hline & SD & 0.021 & 0.010 & 0.041 & 0.051 & 0.096 & 0.029 & 0.015 & 0.018 & 0.006 & 0.012 \\
\hline \multirow[t]{2}{*}{ Cloves } & Mean & 3.550 & 2.830 & 9.450 & 8.333 & 20.833 & 8.333 & 3.417 & 5.383 & 3.800 & 13.050 \\
\hline & SD & 0.012 & 0.019 & 0.027 & 0.034 & 0.084 & 0.052 & 0.014 & 0.049 & 0.011 & 0.038 \\
\hline \multirow[t]{2}{*}{ Melon } & Mean & 4.250 & 4.030 & 9.000 & 7.217 & 18.050 & 7.083 & 3.700 & 2.700 & 3.250 & 3.250 \\
\hline & SD & 0.021 & 0.029 & 0.041 & 0.051 & 0.048 & 0.014 & 0.010 & 0.019 & 0.022 & 0.022 \\
\hline \multirow{2}{*}{$\begin{array}{l}\text { African } \\
\text { Pepper }\end{array}$} & Mean & 6.383 & 3.450 & 7.650 & 5.567 & 19.450 & 4.167 & 2.283 & 5.383 & 3.983 & 2.533 \\
\hline & SD & 0.022 & 0.010 & 0.016 & 0.051 & 0.048 & 0.014 & 0.008 & 0.049 & 0.006 & 0.033 \\
\hline \multirow{2}{*}{$\begin{array}{l}\text { African } \\
\text { Nutmeg }\end{array}$} & Mean & 3.900 & 3.150 & 15.300 & 6.667 & 13.900 & 6.667 & 2.733 & 5.383 & 4.717 & 14.867 \\
\hline & SD & 0.012 & 0.010 & 0.041 & 0.034 & 0.127 & 0.038 & 0.014 & 0.037 & 0.017 & 0.025 \\
\hline \multirow{2}{*}{$\begin{array}{l}\text { Alligator } \\
\text { pepper }\end{array}$} & Mean & 7.083 & 3.760 & 8.100 & 8.333 & 19.433 & 6.250 & 2.733 & 7.000 & 3.067 & 3.250 \\
\hline & SD & 0.044 & 0.019 & 0.027 & 0.034 & 0.096 & 0.066 & 0.014 & 0.049 & 0.017 & 0.022 \\
\hline \multirow[t]{4}{*}{ Nutmeg } & Mean & 4.250 & 3.760 & 9.900 & 10.000 & 18.050 & 5.000 & 2.717 & 6.983 & 3.800 & 3.250 \\
\hline & SD & 0.021 & 0.019 & 0.031 & 0.033 & 0.127 & 0.025 & 0.024 & 0.018 & 0.011 & 0.022 \\
\hline & $\dot{\Xi}$ & $\begin{array}{l}3.200 \\
+0.021\end{array}$ & $\begin{array}{l}2.830 \\
+0.019\end{array}$ & $\begin{array}{l}7.200 \\
+0.041\end{array}$ & $\begin{array}{l}6.667 \\
+0.034\end{array}$ & $\begin{array}{l}9.733 \\
+0.048\end{array}$ & $\begin{array}{l}3.750 \\
+0.025\end{array}$ & $\begin{array}{l}2.717 \\
+0.024\end{array}$ & $\begin{array}{l}2.700 \\
+0.019\end{array}$ & $\begin{array}{l}2.700 \\
\pm 0.011\end{array}$ & $\begin{array}{l}2.533 \\
+0.033\end{array}$ \\
\hline & $\sum^{\stackrel{x}{z}}$ & $\begin{array}{l}7.800 \\
\pm 0.054\end{array}$ & $\begin{array}{l}4.383 \\
+0.011\end{array}$ & $\begin{array}{l}15.300 \pm \\
0.041\end{array}$ & $\begin{array}{l}10.550 \pm \\
0.019\end{array}$ & $\begin{array}{l}20.833 \pm \\
0.084\end{array}$ & $\begin{array}{l}8.333 \\
+0.052\end{array}$ & $\begin{array}{l}4.117 \\
+0.015\end{array}$ & $\begin{array}{l}7.000 \\
+0.049\end{array}$ & $\begin{array}{l}4.717 \\
+0.017\end{array}$ & $\begin{array}{r}14.867 \\
+0.045\end{array}$ \\
\hline
\end{tabular}


Table 4: Heavy metal concentration $(\mathrm{mg} / \mathrm{kg})$ in bulbs

\begin{tabular}{|c|c|c|c|c|c|c|c|c|c|c|}
\hline Bulbs & $\mathrm{Cd}$ & $\mathrm{Cr}$ & $\mathrm{Cu}$ & Co & $\mathrm{Fe}$ & $\mathrm{Mn}$ & $\mathrm{Ni}$ & Mo & $\mathrm{Pb}$ & $\mathrm{Zn}$ \\
\hline Garlic & $5.317 \pm 0.022$ & $3.450 \pm 0.010$ & $10.350 \pm 0.031$ & $13.333 \pm 0.067$ & $12.500 \pm 0.083$ & $6.250 \pm 0.025$ & $4.100 \pm 0.014$ & $5.383 \pm 0.018$ & $5.083 \pm 0.017$ & $21.733 \pm 0.044$ \\
\hline Onion & $6.383 \pm 0.022$ & $5.650 \pm 0.019$ & $9.450 \pm 0.027$ & $8.333 \pm 0.034$ & $10.550 \pm 0.145$ & $5.833 \pm 0.038$ & $3.650 \pm 0.021$ & $5.383 \pm 0.037$ & $4.167 \pm 0.006$ & $2.883 \pm 0.013$ \\
\hline Shallot & $5.317 \pm 0.022$ & $3.767 \pm 0.019$ & $7.200 \pm 0.016$ & $5.000 \pm 0.033$ & $13.900 \pm 0.127$ & $5.833 \pm 0.014$ & $3.633 \pm 0.008$ & $4.850 \pm 0.032$ & $3.250 \pm 0.011$ & $3.250 \pm 0.022$ \\
\hline
\end{tabular}

Table 5: Heavy metals concentration $(\mathrm{mg} / \mathrm{kg})$ in leaves

\begin{tabular}{|c|c|c|c|c|c|c|c|c|c|c|}
\hline Leaves & $\mathrm{Cd}$ & $\mathrm{Cr}$ & $\mathrm{Cu}$ & Co & $\mathrm{Fe}$ & $\mathrm{Mn}$ & $\mathrm{Ni}$ & Mo & $\mathrm{Pb}$ & $\mathrm{Zn}$ \\
\hline Bay leaves & $4.967 \pm 0.044$ & $2.683 \pm 0.006$ & $12.150 \pm 0.027$ & $7.783 \pm 0.051$ & $12.333 \pm 0.083$ & $5.417 \pm 0.058$ & $2.733 \pm 0.014$ & $4.850 \pm 0.032$ & $3.433 \pm 0.006$ & $12.317 \pm 0.034$ \\
\hline Curry leaves & $4.250 \pm 0.021$ & $2.533 \pm 0.011$ & $8.550 \pm 0.041$ & $7.783 \pm 0.020$ & $12.500 \pm 0.083$ & $4.583 \pm 0.014$ & $2.733 \pm 0.010$ & $3.733 \pm 0.050$ & $3.617 \pm 0.013$ & $14.500 \pm 0.012$ \\
\hline Uziza leaves & $5.317 \pm 0.022$ & $3.767 \pm 0.019$ & $9.900 \pm 0.041$ & $6.117 \pm 0.039$ & $13.883 \pm 0.048$ & $5.833 \pm 0.038$ & $3.233 \pm 0.008$ & $4.300 \pm 0.049$ & $3.250 \pm 0.011$ & $3.250 \pm 0.022$ \\
\hline Scent leaves & $7.450 \pm 0.021$ & $5.650 \pm 0.019$ & $12.000 \pm 0.027$ & $9.453 \pm 0.019$ & $20.833 \pm 0.144$ & $6.250 \pm 0.025$ & $2.733 \pm 0.014$ & $4.300 \pm 0.049$ & $2.883 \pm 0.006$ & $2.883 \pm 0.013$ \\
\hline Utazi leaves & $5.317 \pm 0.022$ & $2.533 \pm 0.011$ & $9.900 \pm 0.041$ & $8.333 \pm 0.034$ & $12.500 \pm 0.083$ & $6.250 \pm 0.025$ & $4.333 \pm 0.008$ & $6.450 \pm 0.032$ & $4.167 \pm 0.017$ & $2.167 \pm 0.022$ \\
\hline
\end{tabular}

Table 6: Heavy metals concentration $(\mathrm{mg} / \mathrm{kg})$ in fruit pods

\begin{tabular}{|c|c|c|c|c|c|c|c|c|c|c|}
\hline Fruit pod & $\mathrm{Cd}$ & $\mathrm{Cr}$ & $\mathrm{Cu}$ & $\mathrm{Co}$ & $\mathrm{Fe}$ & $\mathrm{Mn}$ & $\mathrm{Ni}$ & Mo & $\mathrm{Pb}$ & $\mathrm{Zn}$ \\
\hline Red bell pepper & $6.033 \pm 0.013$ & $4.700 \pm 0.019$ & $12.150 \pm 0.011$ & $5.550 \pm 0.019$ & $13.900 \pm 0.127$ & $5.000 \pm 0.050$ & $3.417 \pm 0.014$ & $3.783 \pm 0.018$ & $4.717 \pm 0.023$ & $3.983 \pm 0.013$ \\
\hline Red pepper chili & $5.317 \pm 0.022$ & $3.767 \pm 0.019$ & $11.700 \pm 0.041$ & $7.217 \pm 0.020$ & $16.667 \pm 0.084$ & $5.833 \pm 0.029$ & $2.050 \pm 0.014$ & $5.383 \pm 0.049$ & $3.617 \pm 0.023$ & $3.250 \pm 0.022$ \\
\hline Yellow pepper & $4.600 \pm 0.024$ & $4.700 \pm 0.019$ & $8.100 \pm 0.027$ & $5.567 \pm 0.051$ & $13.883 \pm 0.048$ & $6.250 \pm 0.025$ & $4.333 \pm 0.008$ & $5.383 \pm 0.049$ & $3.067 \pm 0.006$ & $2.517 \pm 0.013$ \\
\hline
\end{tabular}

Table 7: Heavy metals concentration $(\mathrm{mg} / \mathrm{kg})$ in rhizome

\begin{tabular}{|c|c|c|c|c|c|c|c|c|c|c|}
\hline Rhizome & $\mathrm{Cd}$ & $\mathrm{Cr}$ & $\mathrm{Cu}$ & Co & $\mathrm{Fe}$ & $\mathrm{Mn}$ & $\mathrm{Ni}$ & Mo & $\mathrm{Pb}$ & $\mathrm{Zn}$ \\
\hline Ginger & $7.450 \pm 0.021$ & $5.650 \pm 0.019$ & $13.500 \pm 0.027$ & $11.117 \pm 0.069$ & $16.667 \pm 0.084$ & $5.000 \pm 0.043$ & $\begin{array}{l}3.417 \pm 0.01 \\
4\end{array}$ & $\begin{array}{l}5.383 \pm 0.04 \\
9\end{array}$ & $2.700 \pm 0.011$ & $\begin{array}{l}10.133 \pm 0.02 \\
5\end{array}$ \\
\hline
\end{tabular}


The levels of $\mathrm{Cd}, \mathrm{Zn}, \mathrm{Ni}, \mathrm{Mn}, \mathrm{Cu}, \mathrm{Pb}, \mathrm{Fe}, \mathrm{Cr}$, Co, Mo in seeds and their descriptive statistical parameters are shown in Table 3. Cadmium ranged from $3.200 \pm$ 0.021 in baobab seeds to $7.800 \pm 0.054 \mathrm{mg} / \mathrm{kg}$ in castor seeds. Even the lower limit of the range is above the value set for foods or products by the most regulatory bodies. A maximum permissible limit of 1 $\mathrm{mg} / \mathrm{kg}$ was prescribed by the FAO/WHO (2002) for food additives. Threshold values $(\mathrm{mg} / \mathrm{kg}$ ) for cereal grains, leafy vegetables and fruiting vegetables are 0.1, 0.2 and 0.05 (FAO/WHO, 2012). Differently, a value of $0.03 \mathrm{mg} / \mathrm{kg}$ was prescribed by (WHO, 1999a) for medicinal plants in their final dosage form. The level of $\mathrm{Cd}$ in the bulbs, leaves, fruit pods and rhizome are displayed in Table 4, 5, 6and7. The tables show that all $\mathrm{Cd}$ values are evidently above the FAO/WHO limits. The high levels of Cd may not be unconnected with the agricultural practice, the plant and the soil properties (such as calcerous nature of soil) that affect uptake of the metal (Kabata-Pendias, 2011). A few decades back, McGrath (1993) has reported variability in $\mathrm{Cd}$ content $(\mathrm{mg} / \mathrm{kg})$ with plant, showing ranges of $<0.1$ and 0.4 in beans, 0.9 and 8.2 in carrot and 3.6 and 91 .

The mean levels of manganese $(\mathrm{mg} / \mathrm{kg})$ in the seeds (Table 3) ranged from $3.750 \pm 0.025$ in castor seeds to $8.333 \pm 0.052$ in cloves. The normative limit for $\mathrm{Mn}$ in foods has yet to be exactly specified due to nontoxicity of the metal (WHO, 1999b). In fact, plant foodstuff may contain up to $113 \mathrm{mg} / \mathrm{kg}$ of this metal and deficiency manifests within $15-25 \mathrm{mg} / \mathrm{kg}$ (Kabata-Pendias, 2011).Comparatively, the levels of manganese $(\mathrm{mg} / \mathrm{kg})$ in the bulbs (Table 4), leaves (Table 5), fruit pods (Table 6) and rhizome (Table 7) lies within the range of $5.000 \pm 0.043$ to $6.250 \pm$ 0.025 . Generally speaking, the levels of Mn are low in all the spices studied and do not pose any hazard risk.

Lead concentrations $(\mathrm{mg} / \mathrm{kg})$ in the spice seeds range from $2.700 \pm 0.011$ in castor seeds to $4.717 \pm 0.017$ in African nutmeg (Table 3). The range covers the levels found bulbs, leaves, fruit pods and rizhome (Tables 4, 5, 6 and 7, respectively). All the values are above the $2 \mathrm{mg} / \mathrm{kg}$ allowable for food additives (FAO/WHO, 2002) and for most foods $(0.1-2 \mathrm{mg} / \mathrm{kg}$ ) (FAO/WHO, 2012) but lower than the prescribed values for the final dosage form of medicinal plants $(10 \mathrm{mg} / \mathrm{kg})$, which shows that the lead levels in the spice seeds are within tolerable limits. In fact, lead levels above those reported in this study $(6.19 \pm 1.88$ $\mathrm{mg} / \mathrm{kg}$ ) were detected in Egyptian chamomile (AbouArab \& Abou Donia, 2000).

The mean Ni levels in the spice seeds ranged from $2.717 \pm 0.024 \mathrm{mg} / \mathrm{kg}$ in nutmeg to $4.117 \pm 0.015$ $\mathrm{mg} / \mathrm{kg}$ in Ashanti pepper (Table 3) while levels in the bulbs and leaves $(\mathrm{mg} / \mathrm{kg})$ are in the ranges of 3.633 \pm 0.008 to $4.100 \pm 0.014$ and $2.733 \pm 0.010$ to 4.333 \pm 0.008 (Table 4 and 5), respectively. The levels of this metal $(\mathrm{mg} / \mathrm{kg})$ in fruit pods are between 2.050 \pm 0.014 and $4.333 \pm 0.008$ (Table 6). Ginger had chromium content of $3.417 \pm 0.014 \mathrm{mg} / \mathrm{kg}$. The levels of $\mathrm{Ni}$ determined in this study represent potential health risk being well above the requirement of monogastric animals $(0.2 \mathrm{mg} / \mathrm{kg}$ of diet) (WHO, 1999b).Egyptian spicy leaves contained $0.61 \pm 0.26$ to $2.85 \pm 1.85 \mathrm{mg} \mathrm{Ni} / \mathrm{kg}$ (Abou-Arab \& AbouDonia, 2000), which both exceed the limit of $0.6 \mathrm{mg} / \mathrm{day}$ beyond which skin reaction may result in nickelsensitive humans (WHO, 1999b).

Food is the major source of exposure to chromium (WHO, 2008). While $\mathrm{Cr}$ (III) is essential in human body for the improvement of glucose tolerance (Mertz, 1993; Mandiwana et al., 2006) excessive intake, especially of the more oxidizing $\mathrm{Cr}(\mathrm{VI})$, can harm biological systems (Michalski, 2004). The $\mathrm{Cr}(\mathrm{III})(\mathrm{mg} / \mathrm{kg})$ in spice seeds (Table 3) ranged from $2.830 \pm 0.019$ in cloves to $4.383 \pm 0.011$ in efu. The chromium ranges in bulbs, leaves and fruit pods (Table 4, 5 and 6) fall within these limits. However, ginger (Table 7) records the highest level of this metal $(5.650 \pm 0.019 \mathrm{mg} / \mathrm{kg})$. Generally, the accumulation of chromium in edible plants may constitute hazard to animals (Oliveira, 2012). In short, investigation has shown the possibility of phytotoxic effect as chromium levels exceed $1 \mathrm{mg} / \mathrm{kg}$ (Kabata-Pendias, 2011), which clearly shows possible $\mathrm{Cr}$ hazard with consumption of the spices.

The mean concentration of $\mathrm{Cu}$ in the spice seeds ranged from $7.200 \pm 0.041 \mathrm{mg} / \mathrm{kg}$ in Ashanti pepper to $15.300 \pm 0.041 \mathrm{mg} / \mathrm{kg}$ in African nutmeg (Table 3). These levels of $\mathrm{Cu}$ exceed the maximum acceptable daily limit of the metal in crude (fatty) foods ( 0.4 $\mathrm{mg} / \mathrm{kg}$ ) (FAO/WHO, 2012). The levels of this heavy metal in other spice groups such as bulbs, leaves, fruit pods and rizhome are displayed in Tables 4 to 7 . Generally, as adjudged by the joint FAO/WHO standards (FAO/WHO, 2012), all the spices contain excessive copper levels. It is not however surprising as the mean $\mathrm{Cu}$ levels $(\mathrm{mg} / \mathrm{kg})$ in Egyptian chamomile and saffron were found to contain $\mathrm{Cu}$ levels within the same ranges $(8.88 \pm 1.38$ and $11.3 \pm$ 2.4, respectively) (Abou-Arab \& Abou Donia, 2000).

The mean concentration of iron in the seed samples ranged from $9.733 \pm 0.048 \mathrm{mg} / \mathrm{kg}$ in baobab seeds to $20.833 \pm 0.084 \mathrm{mg} / \mathrm{kg}$ in cloves (Table 3 ). The values of this metal in bulbs, leaves, fruit pods and rhizome (Table 4-7) are also within the same bracket. In actual fact, several workers have shown that natural $\mathrm{Fe}$ content of plants can reach orders of $1000 \mathrm{mg} / \mathrm{kg}$ (WHO, 1999a). Various medicinal plants of leaves and herbs category from a number of regions of Austria have been reported to contain levels of iron well above $1000 \mathrm{mg} / \mathrm{kg}$ (Chizzola et al., 2003). 
There has been dramatic increase in the use of $\mathrm{Zn}$ based fertilizers and addition of sludge to the soil under plants, so it is important to monitor the zinc levels in spices. In this study, zinc levels in seeds group ranged from $2.533 \pm 0.033$ in African pepper to $14.867 \pm 0.045$ in efu (Table 3). The highest $\mathrm{Zn}$ content $(\mathrm{mg} / \mathrm{kg})$ was obtained in garlic $21.733 \pm 0.044$ (Table 4). Among leaves group, curry leaves have the highest zinc content $(14.500 \pm 0.012 \mathrm{mg} / \mathrm{kg}$; Table 5). For a high number of plants the upper toxic level of zinc is 100 to $500 \mathrm{mg} / \mathrm{kg}$ (Kabata-Pendias, 2011) which indicates that all the zinc values determined are within tolerable limits.

Molybdenum is an essential constituent of many enzymes. Molybdenum concentration in the seeds group $(\mathrm{mg} / \mathrm{kg})$ ranged from $2.700 \pm 0.019$ in water melon to $7.000 \pm 0.049$ in alligator pepper (Table 3 ). Curry leaves had the lowest molybdenum content (3.733 $\pm 0.050 \mathrm{mg} / \mathrm{kg})$ where as utazi leaves accumulated the largest amount of this metal $(6.450$ \pm 0.032 ; Table 5). Ginger contains $5.383 \pm 0.049 \mathrm{mg}$ $\mathrm{Mo} / \mathrm{kg}$ (Table 7). The molybdenum concentrations of bulbs and fruit pods are close to those of the leaves and seeds groups. All the values of Mo determined in this study are below the threshold of $10 \mathrm{mg} / \mathrm{kg}$ above which most grazing animals encounter serious problems (Kabata-Pendias, 2011).

In the seeds group, cobalt concentrations $(\mathrm{mg} / \mathrm{kg})$ ranged from $6.667 \pm 0.034$ in African nutmeg to $10.550 \pm 0.019$ in cloves (Table 3) while in the bulbs the levels of this metal ranged from $5.000 \pm 0.033$ in shallot to $13.333 \pm 0.067$ in garlic (Table 4). In leaves, the cobalt concentration ranged from $6.117 \pm$ 0.039 in uziza to $9.453 \pm 0.019$ in scent leaves (Table 5).On the other hand, cobalt in fruit pods ranged from $7.217 \pm 0.020$ in red chili pepper to $9.450 \pm 0.027$ in red bell pepper (Table 6). Ginger accumulated $11.117 \pm 0.069 \mathrm{mg} / \mathrm{kg}$ of cobalt (Table 7).The symptoms of phytotoxicity of cobalt become obvious as concentration $(\mathrm{mg} / \mathrm{kg})$ ranges between 30 and 40 , and hazard to animals is likely when concentrations exceed $60 \mathrm{mg} / \mathrm{kg}$ (Kabata-Pendias, 2011).Cobalt is an essential trace element being a component of vitamin
$\mathrm{B}_{12}$ precursor and applicable in treatment of anemic patients (ATSDR, 2004). Therefore, the levels of cobalt determined in all the spice groups may not represent any potential risk.

Human Health Risk: The estimated daily intake (EDI) values of all the heavy metals are displayed in Table 8.The EDI levels of $\mathrm{Cu}$ and $\mathrm{Pb}$ in all the spices were lower than the provisional maximum tolerable intake (PMTDI)of $0.5 \mathrm{mg} / \mathrm{kg}$ day and $0.02-3 \mu \mathrm{g} / \mathrm{kg}$ day set by the joint FAO/WHO committee (FAO/WHO, 2012). Because $\mathrm{Zn}$ is an essential trace element and absorption depends on some other dietary factors (with average intake of $20 \mathrm{mg} /$ day), the lower limit of the joint FAO/WHO standard (0.3-1 $\mathrm{mg} / \mathrm{kg}$ bw) (FAO/WHO, 2012) is often exceeded. In fact, some elemental body formulas contain at least $30 \mathrm{mg} \mathrm{Fe}$ per capsule. The EDI values of cadmium for most of the spices was lower than the PMTDI for this metal $(0.8 \mu \mathrm{g} / \mathrm{kg}$ day) (FAO/WHO, 2012). However, were faced with intolerable EDI values of cadmium, associated with the consumption of onion, ginger, utazi, alligator paper, garlic, Ashanti leaves, castor seeds, and shallot.

As seen from Table 8, cobalt levels in all the spices is above the minimal risk levels for oral intake (MRLOI) (0.01 mg/kg day) recommended by ATSDR (ATSDR, 2016). Similarly, copper levels exceed the risk levels of $0.005 \mathrm{mg} / \mathrm{kg}$ day WHO (1996), meaning potential health risk for the consumers. Zinc with MRLOI of $0.3 \mathrm{mg} / \mathrm{kg}$ day, represents some risk in all the spices except in ginger, locust beans, African nutmeg, cloves, efu, melon seeds, bay leaves and castor seeds. Even though $\mathrm{Cr}$ in all the spices has exceeded the prescribed MRLOI of $0.1 \mu \mathrm{g} / \mathrm{kg}$ day (ATSDR, 2016), tolerable $\mathrm{Cr}$ level could be up to $250 \mu \mathrm{g} /$ day (WHO, 1996). Because the risk level of Mo is 0.14 to $0.20 \mathrm{mg} / \mathrm{kg}$ bw (WHO, 1996), adverse effects are therefore likely to occur with consumption of all the spices except for nutmeg, alligator pepper and utazi. The Ni levels in all the spices are below the WHO permissible limit of 600 $\mu \mathrm{g} /$ day (WHO, 1996), which confirms their safety as food materials. 
Table 8: Estimated daily intake of each metal ( $\mu \mathrm{g} / \mathrm{kg}$ day)

\begin{tabular}{|c|c|c|c|c|c|c|c|c|c|c|}
\hline Spices & $\mathrm{Cr}$ & $\mathrm{Cu}$ & $\mathrm{Co}$ & $\mathrm{Fe}$ & $\mathrm{Mn}$ & $\mathrm{Ni}$ & Mo & $\mathrm{Pb}$ & $\mathrm{Zn}$ & $\mathrm{Cd}$ \\
\hline Ginger & 0.94 & 2.3 & 1.9 & 2.8 & 0.83 & 0.57 & 0.90 & 0.45 & 0.17 & 12 \\
\hline Onion & 0.94 & 1.6 & 1.4 & 1.8 & 0.97 & 0.61 & 0.89 & 0.70 & 0.48 & 1.1 \\
\hline Garlic & 0.57 & 1.7 & 2.2 & 2.1 & 0.10 & 0.68 & 0.90 & 0.85 & 0.36 & 0.89 \\
\hline Nutmeg & 0.63 & 1.7 & 1.7 & 3.0 & 0.83 & 0.45 & 0.12 & 0.63 & 0.54 & 0.71 \\
\hline $\begin{array}{l}\text { Locust } \\
\text { Beans }\end{array}$ & 0.68 & 1.4 & 1.2 & 1.6 & 0.83 & 0.68 & 0.63 & 0.57 & 0.22 & 0.53 \\
\hline $\begin{array}{l}\text { African } \\
\text { nutmeg }\end{array}$ & 0.53 & 2.6 & 1.1 & 2.3 & 0.11 & 0.46 & 0.89 & 0.79 & 0.25 & 0.65 \\
\hline $\begin{array}{l}\text { Alligator } \\
\text { pepper }\end{array}$ & 0.63 & 1.4 & 1.4 & 3.2 & 0.10 & 0.46 & 0.12 & 0.51 & 0.54 & 1.2 \\
\hline Cloves & 0.47 & 1.6 & 1.4 & 3.5 & 0.14 & 0.57 & 0.90 & 0.63 & 0.22 & 0.59 \\
\hline $\begin{array}{l}\text { Ashanti } \\
\text { pepper }\end{array}$ & 0.53 & 1.2 & 1.6 & 3.1 & 0.11 & 0.69 & 1.1 & 0.42 & 2.4 & 0.71 \\
\hline Efu & 0.73 & 1.6 & 1.6 & 2.3 & 0.97 & 0.65 & 0.72 & 0.54 & 0.25 & 0.49 \\
\hline $\begin{array}{l}\text { Ashanti } \\
\text { leaves }\end{array}$ & 0.63 & 1.7 & 1.0 & 2.3 & 0.97 & 0.54 & 0.71 & 0.24 & 0.54 & 0.88 \\
\hline Melon & 0.67 & 1.5 & 1.2 & 3.0 & 0.11 & 0.62 & 0.45 & 0.42 & 0.24 & 0.70 \\
\hline $\begin{array}{l}\text { Curry } \\
\text { leaves }\end{array}$ & 0.42 & 1.4 & 1.3 & 2.1 & 0.76 & 0.46 & 0.62 & 0.60 & 0.17 & 0.82 \\
\hline Utazi & 0.42 & 1.7 & 1.4 & 2.1 & 0.11 & 0.72 & 0.12 & 0.70 & 0.36 & 1.3 \\
\hline Bay leaves & 0.45 & 2.0 & 1.3 & 2.1 & 0.90 & 0.46 & 0.81 & 0.57 & 0.21 & 0.88 \\
\hline $\begin{array}{l}\text { Castor } \\
\text { seed }\end{array}$ & 0.53 & 1.6 & 1.8 & 2.8 & 0.63 & 0.46 & 0.54 & 0.45 & 0.12 & 1.2 \\
\hline Shallot & 0.63 & 1.2 & 8.3 & 2.3 & 0.97 & 0.61 & 0.81 & 0.50 & 0.54 & 0.86 \\
\hline $\begin{array}{l}\text { Scent } \\
\text { leaves }\end{array}$ & 0.94 & 2.0 & 1.6 & 3.4 & 0.10 & 0.46 & 0.72 & 0.48 & 0.48 & 0.77 \\
\hline $\begin{array}{l}\text { Red chili } \\
\text { pepper }\end{array}$ & 0.63 & 1.9 & 1.2 & 2.8 & 0.97 & 0.34 & 0.89 & 0.60 & 0.40 & 0.10 \\
\hline $\begin{array}{l}\text { Yellow } \\
\text { pepper }\end{array}$ & 0.78 & 1.4 & 9.2 & 2.3 & 0.10 & 0.72 & 0.78 & 0.51 & 0.42 & 0.60 \\
\hline $\begin{array}{l}\text { Red bell } \\
\text { pepper }\end{array}$ & 0.78 & 2.0 & 9.3 & 2.3 & 0.83 & 0.57 & 0.63 & 0.79 & 0.67 & 0.31 \\
\hline $\begin{array}{l}\text { African } \\
\text { pepper }\end{array}$ & 0.58 & 1.3 & 9.3 & 3.2 & 0.70 & 0.38 & 0.75 & 0.66 & 0.42 & 0.12 \\
\hline
\end{tabular}

Conclusion: The levels of $\mathrm{Cd}, \mathrm{Cr}, \mathrm{Cu}, \mathrm{Co}, \mathrm{Fe}, \mathrm{Mn}$, $\mathrm{Ni}, \mathrm{Mo}, \mathrm{Pb}, \mathrm{Zn}$ in a spectrum of Nigerian spices was successfully determined using AAS and the health risk associated with intake of these heavy metals has been assessed. The accumulation of heavy metals by spice groups followed the order seeds $>$ leaves $>$ bulb $>$ rhizome $>$ fruit pods. For all the spices investigated, cobalt and copper levels have exceeded the risk levels set by regulatory agencies. African nutmeg contains the highest copper

\section{REFERENCES}

Abou-Arab, AAK; Abou Donia, MA (2000). Heavy metals in Egyptian spices and medicinal plants and the effect of processing on their levels $J$. Agric. Food Chem. 48(6): 2300-2304. concentration, $15.300 \pm 0.041 \mathrm{mg} / \mathrm{kg}$, while ginger contains the highest cobalt value $11.117 \pm 0.069$ $\mathrm{mg} / \mathrm{kg}$. The cadmium hazard was associated with only a few species, and cuts the cross-section of the groups.

Acknowledgement: The authors are grateful to Mal. Muhammad Musa of Research Laboratory, Department of Pure and Industrial Chemistry for his assistance to SA. Ikechukwu.

ATSDR (2004). Agency for Toxic Substances and Disease Registry (ATSDR) Public Health Statement for Cobalt, Retrieved from http://www.atsdr.cdc.gov/PHS/PHS.asp?id=371 $\underline{\text { tid }=64}$ on $6^{\text {th }}$ April, 2016 
ATSDR (2015). Substance Priority List, Agency for toxic substances and disease registry.

(ATSDR), US Department of health and human services Retrieved from http://www.atsdr.cdc.gov/spl/ on $28^{\text {th }}$ April, 2016.

ATSDR(2016) Minimal risk levels Agency for Toxic Substances and Disease Registry (ATSDR) Retrieved from http://www.atsdr.cdc.gov/mrls/mrllist.asp\#17tag on $11^{\text {th }}$ April, 2016.

Barakat, MA(2011). New trends in removing heavy metals from industrial waste water Arabian J. Chem. 4: 361-377.

Brimer, L (2011).Chemical food safety CAB International, United Kingdom.

Cao, H; Chen, J; Zhang, J; Zhang, H; Qiao, L; Men, Y (2010). Heavy metals in rice and garden vegetables and their potential health risks to inhabitants in the vicinity of an industrial zone in Jiangsu, China. J. Environ. Sci. 22: 1792-1799.

Chizzola, R; Michitsch, H; Franz, C (2003) Monitoring of metallic micronutrients and heavy metals in herbs spices and medicinal plants from Austria, Eur. Food Res. Technol. 216: 407-411.

Dukes, JA(2003)CRC Handbook of medicinal spices CRC press, Washington.

FAO/WHO (2002) Limit test for heavy metals in food additive specifications. Explanatory note. Joint FAO/WHO Expert Committee on Food Additives (JECFA).

FAO/WHO (2012). Working document for information and use in discussions related to contaminants and toxins in the GSCTFF. Joint FAO/WHO food standards Programme. CODEX committee on contaminants in foods, Sixth Session, Maastricht, The Netherlands.

Iwegbue, CMA;Overah, CL; Ebigwai, JK; Nwozo, SO; Nwajei, GE; Eguavoen, O (2011). Heavy metal contamination of some vegetables and spices in Nigeria, Int. J. Biol. Chem. Sci. 5(2): 766-773.

Järup, L (2003). Hazards of heavy metal contamination, British Medical Bulletin 68: 167182.

Kabata-Pendias, A (2011). Trace elements in soil and plants. $4^{\text {th }}$ ed. CRC Press Book
Khan, N; Choi, JY; Nho, EY; Jamila, N; Habte, G; Hong, JH; Hwang, IM; Kim, KS (2014). Determination of minor and trace elements in aromatic spices by micro-wave assisted digestion and inductively coupled plasma-mass spectrometry. Food Chem. 158: 200-206.

Krejpcio, Z; Król E; Sionkowski, S (2007). Evaluation of heavy metals contents in spices and herbs available on the Polish market. Pol. J. Env. Stud., 16: 97-100.

Mandal, BK; Suzuki, KT (2002). Arsenic round the world: a review. Talanta. 58: 201-235.

Mandiwana, KL; Panichev, N; Resane, T (2006). Electro thermal atomic absorption determination of total and hexavalent chromium in atmospheric aerosols J. Hazard. Mater. B 136: 379-382.

McGrath, SP (1993). Soil quality in relation to agricultural uses, in integrated soil and sediment research: A Basis for Proper Protection. In: Eijsackers, H. J. P. and T. Hamers, eds., Kluwer Academic, the Netherlands.

Mertz, W(1993). Chromium in human nutrition: A review. J. Nutr. 626-633.

Michalski, R (2004). Ion chromatography method for the determination of trace levels of Chromium (VI) in water. Pol. J. Environ. Stud. 13(1): 73-77.

Obiajunwa, EI; Adebiyi, FM; Omode, PE (2005). Determination of essential minerals and trace elements in Nigerian sesame seeds, using TXRF technique. Pak. J. Nutr. 4(6): 393-395.

Oliveira, H (2012). Chromium as an environmental pollutant: Insights on induced plant Toxicity. $J$. Bot. 375843: 1-8.

WHO (1996). Trace elements in Human Nutrition and Health, WHO, Geneva.

WHO(1999a). Monographs on selected medicinal plants, vol. 1, World Health Organisation (WHO), Geneva.

WHO (1999b) Trace elements in human nutrition and health, World Health Organization

WHO (2008). Guidelines for drinking-water quality, $3^{\text {rd }}$ ed., World Health Organization. 